\title{
Amino acid composition of rumen bacteria and protozoa in cattle
}

\author{
M. Sok, ${ }^{*}$ D. R. Ouellet,† J. L. Firkins, $\ddagger$ D. Pellerin, ${ }^{*}$ and H. Lapierre $\dagger^{1}$ \\ *Department of Animal Sciences, University Laval, Québec, QC, Canada, G1V 0A6 \\ †Agriculture and Agri-Food Canada, Sherbrooke, QC, Canada, J1M 0C8 \\ ‡Department of Animal Sciences, The Ohio State University, Columbus 43210
}

\section{ABSTRACT}

Because microbial crude protein (MCP) constitutes more than $50 \%$ of the protein digested in cattle, its AA composition is needed to adequately estimate AA supply. Our objective was to update the AA contributions of the rumen microbial AA flowing to the duodenum using only studies from cattle, differentiating between fluid-associated bacteria (FAB), particle-associated bacteria $(\mathrm{PAB})$, and protozoa, based on published literature $(53,16$, and 18 treatment means were used for each type of microorganism, respectively). In addition, Cys and Met reported concentrations were retained only when an adequate protection of the sulfur groups was performed before the acid hydrolysis. The total AA (or true protein) fraction represented $82.4 \%$ of CP in bacteria. For 10 AA, including 4 essential AA, the AA composition differed between protozoa and bacteria. The most noticeable differences were a $45 \%$ lower Lys concentration and $40 \%$ higher Ala concentration in bacteria than in protozoa. Differences between $\mathrm{FAB}$ and $\mathrm{PAB}$ were less pronounced than differences between bacteria and protozoa. Assuming 33\% FAB, $50 \% \mathrm{PAB}$, and $17 \%$ of protozoa in MCP duodenal flow, the updated concentrations of AA would decrease supply estimates of Met, Thr, and Val originating from MCP and increase those of Lys and Phe by 5 to $10 \%$ compared with those calculated using the FAB composition reported previously. Therefore, inclusion of the contribution of PAB and protozoa to the duodenal MCP flow is needed to adequately estimate AA supply from microbial origin when a factorial method is used to estimate duodenal AA flow. Furthermore, acknowledging the fact that hydrolysis of $1 \mathrm{~kg}$ of true microbial protein yields $1.16 \mathrm{~kg}$ of free AA substantially increases the estimates of AA supply from MCP.

Key words: cattle, rumen, amino acid, bacteria, protozoa

Received December 13, 2016.

Accepted March 24, 2017.

${ }^{1}$ Corresponding author: Helene.Lapierre@agr.gc.ca

\section{INTRODUCTION}

Duodenal flow of AA is the sum of AA contribution from microbial crude protein (MCP), RUP, and endogenous protein flows. Considering that MCP contributes more than $50 \%$ to duodenal CP flow (Clark et al., 1992), the AA composition of rumen microorganisms must be accurately represented to determine the duodenal flow of AA when a factorial approach is used to estimate AA duodenal flow. To estimate the duodenal flow of AA, however, the NRC (2001) uses a regression approach based on the estimation of EAA duodenal flow from RUP and MCP to duodenal protein flow and the EAA concentration in the RUP fraction. In this way, their estimation of AA duodenal flow was independent of the microbial and endogenous AA composition. However, other models use a factorial approach and therefore need accurate AA composition in MCP. For example, INRAtion (Rulquin et al., 1998) uses the AA composition of fluid-associated bacteria (FAB; Le Hénaff, 1991), which was an average of AA composition obtained from 66 studies conducted in sheep and cattle. The Cornell Net Carbohydrate and Protein System (CNCPS; Fox et al., 2004) model differentiated between the cell wall and non-cell wall AA composition of rumen bacteria. In all models, accurate prediction of the different protein fractions flowing at the duodenum remains a key point of the prediction of duodenal AA flow.

One of the most cited references for the AA composition of rumen bacteria is from Clark et al. (1992), from which 7 of the 18 studies had been performed in sheep. This reference is, however, often used to assess the AA composition of the duodenal MCP flow in cattle (e.g., Pacheco et al., 2006). In addition, part of MCP flowing to the duodenum includes protozoa; indeed, protozoa may contribute 10 to $30 \%$ of duodenal MCP (Sylvester et al., 2005), and their AA composition may differ from that of bacteria (Martin et al., 1996; Volden et al., 1999; Korhonen et al., 2002). Moreover, the particleassociated bacteria (PAB) represent a larger fraction of the bacteria flowing at the duodenum than the FAB (e.g., Reynal and Broderick, 2005; Brito et al., 2007a,b). 
Altogether, these observations clearly indicate that the AA composition of FAB reported by Clark et al. (1992) should not be solely used to assess the contribution of AA from MCP to the AA duodenal flow. Accordingly, the Nordic feed evaluation model (NorFor, 2011) uses a weighted average of the AA composition of 60:30:10 for $\mathrm{PAB}, \mathrm{FAB}$, and protozoa, respectively, but the $\mathrm{AA}$ composition used is based only on 2 studies.

Our hypothesis was that the AA compositions of protozoa and bacteria differ substantially for some AA, whereas the difference between FAB and PAB is more limited. Therefore, the objectives of our study were (1) to update the AA composition of rumen bacteria using only data from cattle, differentiating between FAB and PAB; (2) include AA composition of rumen protozoa in the database; and (3) determine if AA composition differs between protozoa and bacteria, the latter of which are differentiated into FAB and PAB. Because dietary characteristics affected some but not all AA concentrations of microbes (e.g., Hvelplund, 1986; Martin et al., 1996; Mabjeesh et al., 1997), one of our original objectives was to determine the effect of the dietary characteristics on AA profiles of MCP. However, this task could not be completed because the lack of information on composition (e.g., NDF, CP, and starch) of diets and ingredients or, because in many studies, the AA composition of bacteria was reported as a single mean for all diets.

\section{MATERIALS AND METHODS}

Based on an initial search on Scopus (www.scopus. com) completed with a thorough review of referenced manuscripts using cattle, an initial database was built from 29 publications (66 treatment means; between 1967 and 2014) reporting AA composition of FAB, 7 publications (17 treatment means; between 1996 and 2014) reporting AA composition of $\mathrm{PAB}$, and 10 publications (26 treatments; between 1973 and 2006) reporting AA composition of protozoa. When the type of bacteria (i.e., FAB or PAB) was not clearly specified in the manuscript, we evaluated the procedure described in the original manuscript. For most of the studies, it corresponded to FAB, but 5 studies were discarded because a mixture of FAB and $\mathrm{PAB}$ had been reported (Cecava and Parker, 1993; Cunningham et al., 1994; Larsen et al., 2000; Shabi et al., 2000; Jensen et al., 2006). Concentrations of Met and Cys were only kept for studies specifying that the sulfur groups had been protected before hydrolysis; other AA of these studies were kept in the database. The addition of formaldehyde to the ruminal samples altered the ratio of true protein to $\mathrm{CP}$ and, more specifically, concentrations of some AA (Volden and Harstad, 1998). Therefore, data from
2 publications reporting use of formaldehyde (Reynal et al., 2005; Paz et al., 2014) were excluded from the database, plus the data from Volden and Harstad (1998) for the AA composition measured on bacteria extracted using formaldehyde. Two studies reporting Lys concentration lower than $9.0 \mathrm{~g} / 100 \mathrm{~g}$ of AA (Ibrahim and Ingalls, 1972; Reynal et al., 2005) were excluded from the protozoa data set because these low Lys concentrations were a clear indication of contamination from bacteria, feed, or both during the extraction process.

From this database, for each AA, the concentrations outside the range of the mean plus or minus 2 standard deviations were considered outliers and discarded. However, for Cys, His, and Met, the acceptable range was only the mean plus or minus 1 standard deviation; the coefficient of variation $(\mathbf{C V})$ of the reported concentrations of all other AA was below $15 \%$ whereas it was over $25 \%$ for these AA (even when keeping only the studies where a protection of the sulfur group had been made), indicating a technical problem in the analysis of these AA more than just a biological variation. All rumen digesta samples had been collected through rumen cannula, except for the study of Williams and Dinusson (1973), where a stomach tube has been used. The final database contained 22 publications ( 53 treatment means; between 1967 and 2014) for FAB; 7 publications (16 treatment means; between 1996 and 2014) for PAB: and 8 publications (18 treatment means; between 1973 and 2006) for protozoa. Three publications reported FAB, PAB, and protozoa AA concentrations, 4 reported FAB and PAB AA concentrations, 2 reported FAB and protozoa AA concentrations, 13 reported only FAB AA concentrations, and 3 reported only protozoa AA concentrations (for these latter studies bacteria were for a mixture of FAB and PAB or had been isolated using formaldehyde). The number of values available and used from original publications and the number of data excluded are given in Table 1 for each AA. When the sum of the 2 numbers does not add up to the number of total treatment means, it is either because the values were not reported or, for Cys and Met, the sulfur group had not been protected before the hydrolysis. Because no value was reported for the Trp composition in protozoa in the final data set, the value reported in Reynal et al. (2005) was used despite the fact that reported Lys concentrations was low for protozoa. Because data are reported as grams of AA per $100 \mathrm{~g}$ of AA, data discarded were replaced by the mean of the remaining data and values were adjusted for the sum to yield $100 \mathrm{~g}$ of AA/100 g of AA. The true protein content of bacteria has been reported either as grams of AA per $100 \mathrm{~g}$ of $\mathrm{CP}$ or grams of AA-N per $100 \mathrm{~g}$ of total N. When reported as grams of AA per $100 \mathrm{~g}$ of $\mathrm{CP}$, the ratio was divided by 1.16 to account for the addition 
Table 1. Number of values available and used from original publications, and the number of data excluded for each AA

\begin{tabular}{|c|c|c|c|c|c|c|}
\hline \multirow[b]{2}{*}{$\mathrm{AA}$} & \multicolumn{2}{|c|}{$\begin{array}{c}\text { Fluid-associated } \\
\text { bacteria }\end{array}$} & \multicolumn{2}{|c|}{$\begin{array}{c}\text { Particle-associated } \\
\text { bacteria }\end{array}$} & \multicolumn{2}{|c|}{ Protozoa } \\
\hline & Used & Excluded & Used & Excluded & Used & Excluded \\
\hline Ala & 52 & 1 & 12 & 4 & 17 & 1 \\
\hline Arg & 49 & 4 & 13 & 3 & 18 & 0 \\
\hline Asp & 50 & 3 & 16 & 0 & 17 & 1 \\
\hline Cys & 15 & 12 & 8 & 4 & 10 & 4 \\
\hline Glu & 51 & 2 & 14 & 2 & 18 & 0 \\
\hline Gly & 45 & 8 & 13 & 3 & 18 & 0 \\
\hline His & 45 & 8 & 16 & 0 & 12 & 6 \\
\hline Ile & 51 & 2 & 16 & 0 & 18 & 0 \\
\hline Leu & 49 & 4 & 16 & 0 & 17 & 1 \\
\hline Lys & 53 & 0 & 16 & 0 & 18 & 0 \\
\hline Met & 27 & 8 & 10 & 2 & 14 & 4 \\
\hline Phe & 53 & 0 & 16 & 0 & 13 & 1 \\
\hline Pro & 51 & 2 & 15 & 1 & 17 & 1 \\
\hline Ser & 49 & 4 & 16 & 0 & 17 & 1 \\
\hline Thr & 51 & 2 & 14 & 2 & 18 & 0 \\
\hline $\operatorname{Trp}$ & 6 & 0 & 5 & 0 & - & - \\
\hline Tyr & 50 & 3 & 16 & 0 & 10 & 1 \\
\hline Val & 53 & 0 & 16 & 0 & 18 & 0 \\
\hline
\end{tabular}

of 1 molecule of water at the cleavage of each peptide bond during hydrolysis of microbial protein (Storm and Ørskov, 1983; Lapierre et al., 2016). When reported as grams of AA-N per $100 \mathrm{~g}$ of total $\mathrm{N}$, the ratio was divided by 0.93 to account for the loss of 1 atom of $\mathrm{N}$ from Asn to Asp and from Gln to Glu during hydrolysis. Once these corrections were made, the ratios were multiplied by 1.07 to take into account incomplete recovery of AA with a 24-h hydrolysis with a microbial profile (Lapierre et al., 2016); these calculations yielded the proportion of true protein on $\mathrm{CP}$ in bacteria.

Treatment means were averaged within each study and statistical analyses were performed on the AA composition averaged for each study and type of MCP; the number of studies used for each type of microorganism is reported in Table 2. An ANOVA was performed using SAS Institute (2008) with the MIXED procedure, with the main effects being the type of microorganism (i.e., FAB, PAB, or protozoa) and study. Orthogonal contrasts were used to compare the AA composition of (1) the bacteria (FAB + PAB) versus the protozoa and (2) the FAB versus the PAB. An ANOVA with 2 factors, formaldehyde and $\mathrm{FAB}$ versus $\mathrm{PAB}$, was performed to test the effect of the addition of formaldehyde when extracting rumen bacteria on the proportion of true protein to $\mathrm{CP}$ and if the type of bacteria affected this proportion; the interaction was also tested.

\section{RESULTS AND DISCUSSION}

As previously reported in a single study (Volden and Harstad, 1998), the percentage of true protein relative to $\mathrm{CP}$ decreased $(P<0.01)$ by the use of formaldehyde in the extraction process of bacteria, averaging (mean \pm SEM) 71.0 vs. $82.4 \pm 3.7 \%$ with and without formaldehyde, respectively. We found no effect of the type of bacteria (FAB vs. PAB, $P=0.48$ ) and no interaction type of bacteria by formaldehyde $(P=0.59)$. This percentage of true protein relative to $\mathrm{CP}$ (without formaldehyde) is slightly higher than the $80 \%$ usually referred to (e.g., NRC, 2001). The proportion of $80 \%$ of true protein in MCP was mainly based on the overall difference between the total $\mathrm{CP}$ content of rumen bacteria and $\mathrm{CP}$ as RNA and DNA-N and other smaller amounts of NPN; NRC (1985) acknowledged that microbial $\mathrm{N}$ is 0.10 to 0.20 nucleic acid N. However, surprisingly, this $80 \%$ widely used proportion was not strongly supported by data; therefore, we propose that $82.4 \%$ better represents the proportion of true protein in MCP. Indeed, to estimate this percentage, both the incomplete recovery of AA when hydrolyzing a protein for $24 \mathrm{~h}$ and the fact that the complete hydrolysis of 1 $\mathrm{kg}$ of true microbial protein yields $1.16 \mathrm{~kg}$ of free AA have been taken into account, and data for AA composition of bacteria were compiled from 22 studies. As mentioned above, our initial objective was to determine the effect of the diet on MCP composition, but the lack of information on the diets or the report of a single value of MCP composition when more than 1 diet was fed precluded this objective to be pursued.

Mean, minimum, and maximum values and $\mathrm{CV}$ are presented for each type of microorganisms for each AA in Table 2. The CV of the FAB fraction were the highest for Cys, His, and Met, which also was observed 
SOK ET AL.

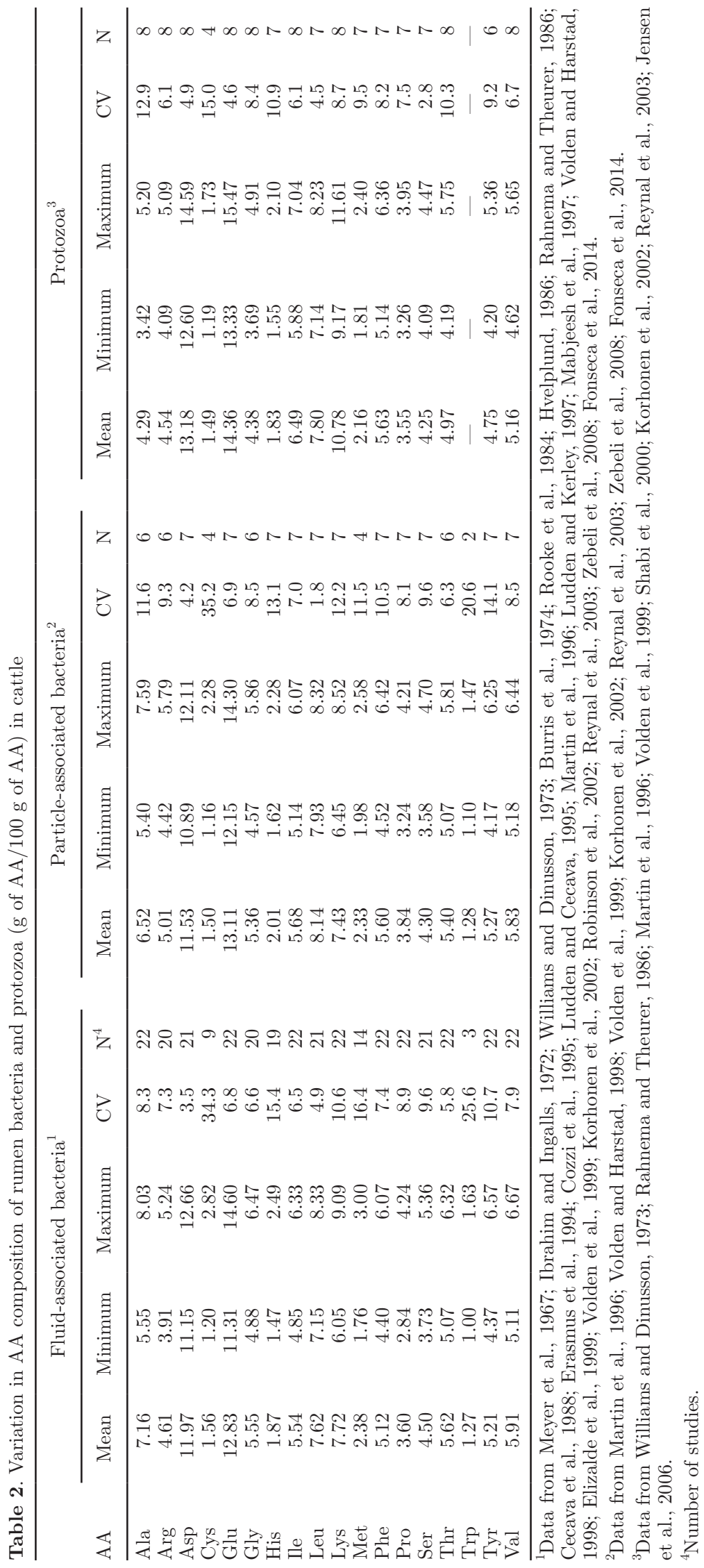


by Clark et al. (1992) for His and Met (Cys was not reported). Overall, the $\mathrm{CV}$ of the data used in the analysis for the FAB fraction were lower than those reported by Clark et al. (1992) because we had more data and removed outliers. Regarding Met and Cys analysis, it is important to protect their sulfur group using a performic acid oxidation before the hydrolysis to oxidize the Cys and Met to the more stable compounds, cysteic acid and methionine sulfone, respectively. In the current database, because of the limited number of studies that reported the use of performic acid oxidation before hydrolysis, we also retained Met concentrations from studies that specified other types of protection of the sulfur groups of AA. Indeed, mean Met concentrations were very similar when performic acid oxidation had been used, averaging (mean \pm SD) $2.39 \pm 0.43 \mathrm{~g} / 100 \mathrm{~g}$ of AA (29 values) versus when another type of protection had been used at $2.41 \pm$ $0.42 \mathrm{~g} / 100 \mathrm{~g}$ of AA (8 values). When no protection was made before the hydrolysis, Met concentration averaged $2.23 \pm 0.54 \mathrm{~g} / 100 \mathrm{~g}$ of AA (14 values), indicating only $93 \%$ recovery without the protection. However, Met concentrations of FAB in the current analysis was similar to those reported by Clark et al. (1992) and Le Hénaff (1991), who did not mention protection of the sulfur group of Met before hydrolysis. Cysteine is less stable than Met during acid hydrolysis (Rutherfurd et al., 2007), but this could not be assessed in the current analysis because Cys concentrations were only reported when performic acid oxidation had been performed before hydrolysis.

For $10 \mathrm{AA}$, including 4 EAA, the AA composition differed $(P \leq 0.05)$ between protozoa and bacteria (Table $3)$. The most noticeable differences were a $45 \%$ lower Lys concentration and $40 \%$ higher Ala concentration in bacteria than protozoa. Of the other EAA, Ile was lower (17\%), whereas Thr $(9 \%)$ and Val $(16 \%)$ were higher in bacteria than protozoa. Only the 3 studies comparing the $\mathrm{AA}$ composition of $\mathrm{FAB}, \mathrm{PAB}$, and protozoa reported statistical analyses comparing bacteria and protozoa concentrations. In agreement with our data, Lys concentration was consistently higher by more than $50 \%$ in protozoa than in bacteria (Martin et al., 1996; Volden et al., 1999; Korhonen et al., 2002). For other studies reporting composition of protozoa and $\mathrm{FAB}$ (Williams and Dinusson, 1973; Rahnema and Theurer, 1986) or the composition of protozoa and a mixture of FAB and PAB (Shabi et al., 2000; Jensen et al., 2006), although no statistics were made to delineate significant differences, Lys concentration was consistently higher in protozoa than in bacteria. Protozoa metabolize the diaminopimelic acid in bacterial cell walls to Lys (Martin et al., 1996), but the high Lys might also indicate accumulation for some as yet unknown reason. As observed in the current analysis, although not always being significant, the same trends for higher concentrations of Asp, Glu, and Ile in protozoa than in bacteria were observed within studies, except in Williams and Dinusson (1973) where Glu concentrations were numerically similar between bacteria and protozoa. Also, as observed in the current analysis, higher concentrations of Ala, Gly, Pro, Ser, Thr, and Val were observed in bacteria than in protozoa in the studies mentioned above, except for Williams and Dinusson (1973), where Thr concentrations were numerically similar between bacteria and protozoa. These significant differences in the AA composition of bacteria and protozoa clearly indicate the importance of acknowledging the presence of protozoa in duodenal MCP flow to correctly predict the AA duodenal flow. If protozoal outflow is enhanced, the protozoal Lys contribution was projected to be significant (Jouany, 1996); unfortunately, then as now, there is a virtually complete lack of studies that clearly modified the abundance of ruminal and duodenal flow of protozoa while measuring duodenal AA flows.

Because of the simplicity of rumen fluid sampling for isolating FAB compared with methods required to dislodge and recover PAB, most of the studies reporting the AA composition of bacteria harvested and analyzed only the FAB fraction. Even so, bacteria are clearly acknowledged to be associated with 2 phases, the FAB and $\mathrm{PAB}$, with $\mathrm{PAB}$ representing the most prevalent fraction of the duodenal bacteria flow (e.g., Reynal and Broderick, 2005; Brito et al., 2007a,b). Differences in $\mathrm{AA}$ composition between $\mathrm{FAB}$ and $\mathrm{PAB}$ were less pronounced than between protozoa and bacteria, but still significant. Concentrations of Ala, Gly, and Thr were higher $(P \leq 0.05)$ in $\mathrm{FAB}$ than in $\mathrm{PAB}$, whereas concentrations of Arg, Leu, Phe, and Pro were lower $(P<0.05)$ in FAB than in PAB (Table 3$)$. In studies from which the AA composition of both fractions were reported, the same differences or trends were observed for the EAA, Arg, Leu, and Phe. The lower Phe concentration in FAB than in PAB and also in protozoa might partially explain why the digestive flows of Phe predicted using a factorial approach and the AA composition reported by Clark et al. (1992) for FAB, were systematically lower than the measured net portal absorption (Pacheco et al., 2006).

The best option to adequately estimate the AA duodenal flow would be to have models predicting both bacteria and protozoa duodenal flows. Because data are currently lacking to develop such a model, using a composite AA concentration of MCP including FAB, PAB, and protozoa rather than only FAB is an option that can be used immediately and should improve the predictions of AA duodenal flows. The major point herein was to determine the ratio of FAB-to-PAB-to-protozoa 
Table 3. Amino acid composition of rumen bacteria and protozoa (g of AA/100 g of AA) in cattle

\begin{tabular}{|c|c|c|c|c|c|c|}
\hline \multirow[b]{2}{*}{$\mathrm{AA}$} & \multirow[b]{2}{*}{$\mathrm{FAB}^{1}$} & \multirow[b]{2}{*}{$\mathrm{PAB}^{2}$} & \multirow[b]{2}{*}{ Protozoa } & \multirow[b]{2}{*}{$\mathrm{SEM}^{3}$} & \multicolumn{2}{|c|}{ Contrast, $P$-value } \\
\hline & & & & & $\begin{array}{c}\text { Bacteria } \\
\text { vs. protozoa }\end{array}$ & FAB vs. PAB \\
\hline Ala & 7.21 & 6.73 & 4.18 & 0.12 & $<0.001$ & 0.006 \\
\hline Arg & 4.59 & 4.87 & 4.50 & 0.11 & 0.10 & 0.04 \\
\hline Asp & 11.92 & 11.58 & 13.37 & 0.24 & $<0.001$ & 0.21 \\
\hline Cys & 1.41 & 1.76 & 1.90 & 0.27 & 0.39 & 0.28 \\
\hline Glu & 12.85 & 12.68 & 14.43 & 0.24 & $<0.001$ & 0.53 \\
\hline Gly & 5.56 & 5.29 & 4.30 & 0.07 & $<0.001$ & 0.02 \\
\hline His & 1.87 & 1.92 & 1.78 & 0.06 & 0.14 & 0.51 \\
\hline Ile & 5.52 & 5.56 & 6.47 & 0.08 & $<0.001$ & 0.73 \\
\hline Leu & 7.59 & 8.15 & 7.96 & 0.10 & 0.45 & $<0.001$ \\
\hline Lys & 7.62 & 7.49 & 10.93 & 0.16 & $<0.001$ & 0.44 \\
\hline Met & 2.37 & 2.26 & 2.23 & 0.11 & 0.50 & 0.42 \\
\hline Phe & 5.17 & 5.58 & 5.50 & 0.09 & 0.28 & $<0.001$ \\
\hline Pro & 3.64 & 3.94 & 3.32 & 0.07 & $<0.001$ & $<0.001$ \\
\hline Ser & 4.53 & 4.46 & 4.12 & 0.09 & 0.005 & 0.42 \\
\hline Thr & 5.60 & 5.28 & 4.97 & 0.12 & 0.008 & 0.05 \\
\hline Trp & 1.27 & 1.24 & $0.82^{4}$ & 0.11 & - & 0.85 \\
\hline Tyr & 5.20 & 5.23 & 4.96 & 0.17 & 0.21 & 0.85 \\
\hline Val & 5.97 & 5.80 & 4.93 & 0.13 & $<0.001$ & 0.23 \\
\hline
\end{tabular}

in the duodenal protein flow to calculate composite concentration. Because of problems with overlap of various other marker approaches when trying to quantify protozoal N outflow (Firkins et al., 1998, 2007), the literature was searched for dairy studies in which bacterial and protozoal flow were derived using independent marker approaches (Robinson et al., 1996; Shabi et al., 2000; Reynal et al., 2003, 2005; Sylvester et al., 2005; Castillo-Lopez et al., 2013, 2014). After weighting the data for the inverse of standard error of the means, none of the approaches used (quantitative PCR, phosphatidylcholine, or optimization of AA profiles) were different $(P=0.85)$. The percentage of protozoa relative to microbial $\mathrm{N}$ reaching the duodenum was 16.5 $(\mathrm{SE}=1.8)$ when the data were weighted for the inverse of standard error of the means from the original papers and was $18.8(\mathrm{SE}=3.3)$ when not weighted. Firkins et al. (2007) argued that increased DMI by high-producing dairy cattle lowers ruminal protozoa pool size and increases outflow rate of protozoa (entodiniomorphids are assumed to pass at the same rate as the potentially degradable particulate matter). Passage rates typically are assigned as first-order fractional rates, which are a proportion of the ruminal pool size passing per hour. Because flow $(\mathrm{g} / \mathrm{d})$ equals pool size $(\mathrm{g})$ multiplied by passage rate $(/ \mathrm{h})$ multiplied by $24 \mathrm{~h} / \mathrm{d}$, decreasing the protozoal pool size in the rumen relative to total MCP pool size can still decrease flow of protozoal CP $(\mathrm{g} / \mathrm{d})$ even if the fractional passage rate increases moderately.
Hence, the $16.5 \%$ of MCP arising from protozoal protein in the current analysis is somewhat lower than the mean of $23 \%$ in nonlactating ruminants (Hristov and Jouany, 2005) but appears justified. The remainder $(83.5 \%)$ is distributed between FAB and PAB, at 40 and $60 \%$, respectively (e.g., Reynal and Broderick, 2005; Brito et al., 2007a,b). The MCP flows therefore assume that $16.5 \%$ of MCP is protozoal N, $33.4 \%$ FAB and $50.1 \% \mathrm{PAB}$. We noted that fungal protein contributes to MCP, but quantitative results were insufficient to include their contribution.

As previously mentioned, the proportion of the 3 microbial fractions in MCP might vary, but not enough data exist to build a robust model including this type of variation. Recognizing that constraint and using the proportions detailed above, the AA composition of a composite MCP was calculated (Table 4) and compared with the FAB composition reported by Clark et al. (1992) and Le Hénaff (1991). Concentration of Met was lower in the current proposition because of the inclusion of the PAB and protozoa concentrations, which were numerically lower in Met than the FAB in the current analysis (Table 3). For the EAA, using the composite AA concentrations from a mixture of FAB, $\mathrm{PAB}$, and protozoa would decrease, for the EAA, the weighted mean of Met, Thr, and Val and increase Lys and Phe in MCP by 5 to $10 \%$, thus changing predicted flows of these AA compared with the flows predicted using the FAB composition reported by Clark et al. 
Table 4. Comparison of microbial protein AA composition obtained in the current study with basic references

\begin{tabular}{|c|c|c|c|c|}
\hline \multirow[b]{2}{*}{$\mathrm{AA}$} & \multicolumn{3}{|c|}{$\mathrm{g}$ of $\mathrm{AA} / 100 \mathrm{~g}$ of $\mathrm{AA}$} & \multirow[b]{2}{*}{$\begin{array}{l}\mathrm{g} \text { of } \mathrm{AA} / 100 \mathrm{~g} \\
\text { of true protein }\end{array}$} \\
\hline & Current $^{2}$ & $\begin{array}{c}\text { Clark et al., } \\
1992^{3}\end{array}$ & $\begin{array}{l}\text { Le Hénaff, } \\
1991^{3}\end{array}$ & \\
\hline$\overline{\mathrm{Ala}}$ & 6.47 & 7.27 & 7.59 & 7.36 \\
\hline Arg & 4.72 & 4.95 & 4.77 & 5.29 \\
\hline Asp & 11.99 & 11.84 & 11.78 & 13.38 \\
\hline Cys & 1.67 & 1.38 & 1.37 & 2.23 \\
\hline Glu & 13.02 & 12.71 & 12.94 & 14.97 \\
\hline Gly & 5.22 & 5.63 & 5.55 & 6.18 \\
\hline His & 1.88 & 1.94 & 1.75 & 2.08 \\
\hline Ile & 5.71 & 5.53 & 5.74 & 6.95 \\
\hline Leu & 7.93 & 7.85 & 7.49 & 9.22 \\
\hline Lys & 8.10 & 7.67 & 7.79 & 9.37 \\
\hline Met & 2.29 & 2.52 & 2.43 & 2.61 \\
\hline Phe & 5.43 & 4.95 & 5.16 & 6.43 \\
\hline Pro & 3.74 & 3.59 & 3.60 & 4.25 \\
\hline Ser & 4.43 & 4.47 & 4.48 & 5.44 \\
\hline Thr & 5.34 & 5.63 & 5.64 & 6.29 \\
\hline Trp & 1.18 & 1.27 & 1.27 & 1.43 \\
\hline Tyr & 5.18 & 4.75 & 4.57 & 6.05 \\
\hline Val & 5.71 & 6.02 & 6.03 & 6.90 \\
\hline
\end{tabular}

${ }^{1}$ From current study, but corrected to acknowledge that the AA are present in anhydrous form in proteins and corrected for the fact that after a 24-h hydrolysis of the proteins, the recovery of the AA is not complete. ${ }^{2}$ Assuming $33.4 \%$ fluid-associated bacteria, $50.1 \%$ particle-associated bacteria, and $16.5 \%$ protozoa.

${ }^{3}$ AA composition of fluid-associated bacteria (FAB); Cys and Trp FAB concentrations (Table 3) were added to Clark et al. (1992) and Le Hénaff (1991) and concentrations adjusted to yield a sum of $100 \mathrm{~g}$ of AA/100 g of AA.

(1992). Variations resulting from the utilization of the AA profile of the MCP mixture rather than the FAB composition reported by Le Hénaff (1991) follow the same trend, except for His and Leu flow estimates, which increase when using the current proposition. In addition, for future reference, the AA composition of the true protein of $\mathrm{MCP}$, corrected for the incomplete recovery of all AA after a 24-h hydrolysis (e.g., Rutherfurd et al., 2008: Lapierre et al., 2016) and taking into account that AA are present under anhydrous form in proteins (Lapierre et al., 2016), is reported in Table 4. With this later phenomenon, the sum of the composition of free AA from protein hydrolysis should weigh approximately $16 \%$ more than the weight of the true microbial protein because of the addition of 1 molecule of water each time a peptide bond is cleaved. With the profile of microbial protein we propose, $1 \mathrm{~kg}$ of true protein would yield $1.16 \mathrm{~kg}$ of free AA after complete hydrolysis. Therefore, estimation of AA duodenal flow originating from microbial protein using this latter AA profile of true protein from microbial origin will substantially increase the estimates of AA duodenal flow from MCP compared with usage of the composition in grams of AA per $100 \mathrm{~g}$ of AA, which had been commonly used (e.g., Pacheco et al., 2006). Should this composition be used in future models, adjustments will be needed to determine the breaking point of the broken line representing the requirement as the percent of
AA per MP, if the proportional approach is used, or of the efficiency of utilization of the AA, if the factorial approach is used, to assess individual AA requirements.

\section{CONCLUSIONS}

Based on rigorous screening and quantification approaches, the information from our literature search and statistical analysis on AA composition of the different fractions of MCP in cattle will improve the accuracy and precision in predicting AA supply using a factorial approach to estimate AA duodenal flow compared with the assignment of the AA composition of ovine and bovine FAB fraction to the whole MCP flow. The importance of conducting a focused study on cattle was necessary to more correctly assess the contribution of MCP to AA duodenal flow. Further studies are needed to assess the potential for varying AA profile and differential passage of PAB relative to FAB and between bacteria $(\mathrm{FAB}+\mathrm{PAB})$ and protozoa in cattle under different dietary conditions.

\section{ACKNOWLEDGMENTS}

The financial support of the Dairy Farmers of Canada (Ottawa, ON, Canada), Agriculture and Agri-Food Canada (Sherbrooke, QC, Canada), and the Natural Sciences and Engineering Research Council of Canada 
(Ottawa, ON, Canada) is acknowledged. The statistical advice of Steve Methot (Agriculture and Agri-Food Canada) has also been greatly appreciated.

\section{REFERENCES}

Brito, A. F., G. A. Broderick, J. J. O. Colmenero, and S. M. Reynal. 2007b. Effects of feeding formate-treated alfalfa silage or red clover silage on omasal nutrient flow and microbial protein synthesis in lactating dairy cows. J. Dairy Sci. 90:1392-1404.

Brito, A. F., G. A. Broderick, and S. M. Reynal. 2007a. Effects of different protein supplements on omasal nutrient flow and microbial protein synthesis in lactating dairy cows. J. Dairy Sci. 90:18281841.

Burris, W. R., N. W. Bradley, and J. A. Boling. 1974. Amino acid availability of isolated rumen microbes as affected by protein supplement. J. Anim. Sci. 38:200-205.

Castillo-Lopez, E., T. J. Klopfenstein, S. C. Fernando, and P. J. Kononoff. 2013. In vivo determination of rumen undegradable protein of dried distillers grains with solubles and evaluation of duodenal microbial crude protein flow. J. Anim. Sci. 91:924-934.

Castillo-Lopez, E., H. A. Ramirez Ramirez, T. J. Klopfenstein, D. Hostetler, K. Karges, S. C. Fernando, and P. J. Kononoff. 2014 Ration formulations containing reduced-fat dried distillers grains with solubles and their effect on lactation performance, rumen fermentation, and intestinal flow of microbial nitrogen in Holstein cows. J. Dairy Sci. 97:1578-1593.

Cecava, M. J., N. R. Merchen, L. L. Berger, and G. C. Fahey Jr. 1988. Effects of dietary energy level and protein source on site of digestion and duodenal nitrogen and amino acid flows in steers. J. Anim. Sci. 66:961-974.

Cecava, M. J., and J. E. Parker. 1993. Intestinal supply of amino acids in steers fed ruminally degradable and undegradable crude protein sources alone or in combination. J. Anim. Sci. 71:1596-1605.

Clark, J. H., T. H. Klusmeyer, and M. R. Cameron. 1992. Microbial protein synthesis and flows of nitrogen fractions to the duodenum of dairy cows. J. Dairy Sci. 75:2304-2323.

Cozzi, G., I. Andrighetto, P. Berzaghi, and C. E. Polan. 1995. In situ ruminal disappearance of essential amino acids in protein feedstuffs. J. Dairy Sci. 78:161-171.

Cunningham, K. D., M. J. Cecava, and T. R. Johnson. 1994. Flows of nitrogen and amino acids in dairy cows fed diets containing supplemental feather meal and blood meal. J. Dairy Sci. 77:3666-3675.

Elizalde, J. C., N. R. Merchen, and D. B. Faulkner. 1999. Supplemental cracked corn for steers fed fresh alfalfa: II. Protein and amino acid digestion. J. Anim. Sci. 77:467-475.

Erasmus, L. J., P. M. Botha, and H. H. Meissner. 1994. Effect of protein source on ruminal fermentation and passage of amino acids to the small intestine of lactating cows. J. Dairy Sci. 77:3655-3665.

Firkins, J. L., M. S. Allen, B. S. Oldick, and N. R. St-Pierre. 1998. Modeling ruminal digestibility of carbohydrates and microbial protein flow to the duodenum. J. Dairy Sci. 81:3350-3369.

Firkins, J. L., Z. Yu, and M. Morrison. 2007. Ruminal nitrogen metabolism: Perspectives for integration of microbiology and nutrition for dairy. J. Dairy Sci. 90(E. Suppl.):1-16.

Fonseca, A. C., S. M. Fredin, L. F. Ferraretto, C. M. Parsons, P. L. Utterback, and R. D. Shaver. 2014. Short communication: Intestinal digestibility of amino acids in fluid- and particle-associated rumen bacteria determined using a precision-fed cecectomized rooster bioassay. J. Dairy Sci. 97:3855-3859.

Fox, D. G., L. O. Tedeschi, T. P. Tylutki, J. B. Russell, M. E. Van Amburgh, L. E. Chase, A. N. Pell, and T. R. Overton. 2004. The Cornell Net Carbohydrate and Protein System model for evaluating herd nutrition and nutrient excretion. Anim. Feed Sci. Technol. 112:29-78

Hristov, A. N., and J.-P. Jouany. 2005. Factors affecting the efficiency of nitrogen utilization in the rumen. Pages 117-166 in Nitrogen and Phosphorus Nutrition of Cattle. Reducing the Environmental Impact of Cattle Operations. A. N. Hristov and E. Pfeffer, ed. CAB International, Wallingford, UK.
Hvelplund, T. 1986. The influence of diet on nitrogen and amino acid content of mixed rumen bacteria. Acta Agric. Scand. 35:325-331.

Ibrahim, E. A., and J. R. Ingalls. 1972. Microbial protein biosynthesis in the rumen. J. Dairy Sci. 55:971-978.

Jensen, C., M. R. Weisbjerg, and T. Hvelplund. 2006. Evaluation of methods for estimating the amino acid supply to the duodenum of microbial, endogenous and undegraded feed protein on maize silage diets fed to dairy cows. Anim. Feed Sci. Technol. 131:1-24.

Jouany, J.-P. 1996. Effect of rumen protozoa on nitrogen utilization by ruminants. J. Nutr. 126:1335S-1346S.

Korhonen, M., A. Vanhatalo, and P. Huhtanen. 2002. Effect of protein source on amino acid supply, milk production, and metabolism of plasma nutrients in dairy cows fed grass silage. J. Dairy Sci. 85:3336-3351.

Lapierre, H., D. R. Ouellet, R. Martineau, and J. W. Spek. 2016. Key roles of amino acids in cow performance and metabolism - considerations for defining amino acid requirment. Pages 205-219 in Proc. Cornell Nutrition Conference for feed manufacturers. Cornell University, Ithaca, NY.

Larsen, M., T. G. Madsen, M. R. Weisbjerg, T. Hvelplund, and J. Madsen. 2000. Endogenous amino acid flow in the duodenum of dairy cows. Acta Agric. Scand. A Anim. Sci. 50:161-173.

Le Hénaff, L. 1991. Importance des acides aminés dans la nutrition des vaches laitières. PhD thesis. Département des Sciences de la vie et de l'Environment, Université de Rennes, Rennes, France.

Ludden, P. A., and M. J. Cecava. 1995. Supplemental protein sources for steers fed corn-based diets: I. Ruminal characteristics and intestinal amino acid flows. J. Anim. Sci. 73:1466-1475.

Ludden, P. A., and M. S. Kerley. 1997. Amino acid and energy interrelationships in growing beef steers: I. The effect of level of feed intake on ruminal characteristics and intestinal amino acid flows. J. Anim. Sci. 75:2550-2560.

Mabjeesh, S. J., A. Arieli, I. Bruckental, S. Zamwell, and H. Tagari. 1997. Effect of ruminal degradability of crude protein and nonstructural carbohydrates on the efficiency of bacterial crude protein synthesis and amino acid flow to the abomasum of dairy cows. J. Dairy Sci. 80:2939-2949.

Martin, C., L. Bernard, and B. Michalet-Doreau. 1996. Influence of sampling time and diet on amino acid composition of protozoal and bacterial fractions from bovine ruminal contents. J. Anim. Sci. 74:1157-1163.

Meyer, R. M., E. E. Bartley, C. W. Deyoe, and V. F. Colenbrander. 1967. Feed processing. I. Ration effects on rumen microbial protein synthesis and amino acid composition. J. Dairy Sci. 50:1327-1332.

NorFor. 2011. The Nordic Feed Evaluation System. H. Volden, ed EAAP Pub. No 130. Wageningen Academic Publishers, the Netherlands.

NRC. 1985. Ruminant Nitrogen Use. Natl. Acad. Press, Washington, DC.

NRC. 2001. Nutrient Requirements of Dairy Cattle. 7th rev. ed. Natl. Acad. Sci., Washington, DC.

Pacheco, D., C. G. Schwab, R. Berthiaume, G. Raggio, and H. Lapierre. 2006. Comparison of net portal absorption with predicted flow of digestible amino acids: Scope for improving current models? J. Dairy Sci. 89:4747-4757.

Paz, H. A., T. J. Klopfenstein, D. Hostetler, S. C. Fernando, E. Castillo-Lopez, and P. J. Kononoff. 2014. Ruminal degradation and intestinal digestibility of protein and amino acids in high-protein feedstuffs commonly used in dairy diets. J. Dairy Sci. 97:64856498.

Rahnema, S. H., and B. Theurer. 1986. Comparison of various amino acids for estimation of microbial nitrogen in digesta. J. Anim. Sci. 63:603-612.

Reynal, S. M., and G. A. Broderick. 2005. Effect of dietary level of rumen-degraded protein on production and nitrogen metabolism in lactating dairy cows. J. Dairy Sci. 88:4045-4064.

Reynal, S. M., G. A. Broderick, S. Ahvenjärvi, and P. Huhtanen. 2003 Effect of feeding protein supplements of differing degradability on omasal flow of microbial and undegraded protein. J. Dairy Sci. 86:1292-1305. 
Reynal, S. M., G. A. Broderick, and C. Bearzi. 2005. Comparison of four markers for quantifying microbial protein flow from the rumen of lactating dairy cows. J. Dairy Sci. 88:4065-4082.

Robinson, P. H., J. G. Fadel, and M. Ivan. 1996. Critical evaluation of diaminopimelic acid and ribonucleic acid as markers to estimate rumen pools and duodenal flows of bacterial and protozoal nitrogen. Can. J. Anim. Sci. 76:587-597.

Robinson, P. H., M. Gill, and J. J. Kennelly. 2002. Influence of time of feeding a protein meal on diurnal patterns of amino acids in duodenal digesta protein of lactating dairy cows. Anim. Feed Sci. Technol. 97:115-121.

Rooke, J. A., H. A. Greiffe, and D. G. Armstrong. 1984. The effect of in sacco rumen incubation of a grass silage upon the total and Damino acid composition of the residual silage dry matter. J. Agric. Sci. 102:695-702.

Rulquin, H., J. Guinard, and R. Vérité. 1998. Variation of amino acid content in the small intestine digesta of cattle: Development of a prediction model. Livest. Prod. Sci. 53:1-13.

Rutherfurd, S. M., P. J. Moughan, D. Lowry, and C. G. Prosser. 2008. Amino acid composition determined using multiple hydrolysis times for three goat milk formulations. Int. J. Food Sci. Nutr. 59:679-690.

Rutherfurd, S. M., A. Schneuwly, and P. J. Moughan. 2007. Analyzing sulfur amino acids in selected feedstuffs using least-squares nonlinear regression. J. Agric. Food Chem. 55:8019-8024.

SAS Institute. 2008. SAS User's Guide. SAS Institute Inc., Cary, NC.

Shabi, Z., H. Tagari, M. R. Murphy, I. Bruckental, S. J. Mabjeesh, S. Zamwel, K. Celik, and A. Arieli. 2000. Partitioning of amino acids flowing to the abomasum into feed, bacterial, protozoal, and endogenous fractions. J. Dairy Sci. 83:2326-2334.

Storm, E., and E. R. Ørskov. 1983. The nutritive value of rumen micro-organisms in ruminants. I. Large-scale isolation and chemical composition of rumen micro-organisms. Br. J. Nutr. 50:463-470.

Sylvester, J. T., S. K. R. Karnati, Z. Yu, C. J. Newbold, and J. L. Firkins. 2005. Evaluation of a real-time PCR assay quantifying the ruminal pool size and duodenal flow of protozoa nitrogen. J. Dairy Sci. 88:2083-2095.

Volden, H., and O. M. Harstad. 1998. Amino acid composition of bacteria harvested from the rumen of dairy cows fed three diets differing in protein content and rumen protein degradability at two levels of intake. Acta Agric. Scand. A Anim. Sci. 48:210-215.

Volden, H., O. M. Harstad, and L. T. Mydland. 1999. Amino acid content and profile of protozoal and bacterial fractions isolated from ruminal contents of lactating dairy cows fed diets differing in nitrogen supplementation. Acta Agric. Scand. A Anim. Sci. 49:245-250.

Williams, P. P., and W. E. Dinusson. 1973. Amino acid and fatty acid composition of bovine ruminal bacteria and protozoa. J. Anim. Sci. 36:151-155.

Zebeli, Q., M. Tafaj, B. Junck, D. Mansmann, H. Steingass, and W. Drochner. 2008. Evaluation of the effects of dietary particle fractions on fermentation profile and concentration of microbiota in the rumen of dairy cows fed grass silage-based diets. Arch. Anim. Nutr. 62:230-240. 